\title{
KAJIAN KEBUGARAN WANITA DARI ASPEK KECUKUPAN GIZI, STATUS GIZI DAN AKTIVITAS
}

\author{
Sri Sugiarsi \\ APIKES Mitra Husada Karanganyar \\ Jl. Achmad Yani No.167 Papahan, Tasikmadu, Karanganyar
}

\begin{abstract}
The level of fitness can be reached by having good nutrition, doing exercise and spending some times for sleeping sufficienly. Purpose of this study was to examine the relationship between nutritional intake, nutritional status, adequate sleep and exercise in women's fitness in the Taurus gymnasium Center of Surabaya. Respondents of this research were 60 members of Taurus gymnasium. This was cross sectional analytical study to show the influence of variables of the sufficiency of nutrition (calory, carbohydrate, protein, vitamin B1, fat, calcium), nutritional status and activity and the level of fitness. The result of the statistical test with $=0,05$ showed that there is a significant relationship between sufficiency of iron element and frequency of exercise and the level of fitness. It is sugested for members of Taurus gymnasium Center to do exercise regulary and improve eating pattern by consuming various menu, much more non heme protein than heme protein, and consuming vitamin C sufficienly.
\end{abstract}

Keywords : Fitness, Nutritional Intake, Exercise

\section{PENDAHULUAN}

Wanita di Indonesia terutama sebagai ibu rumah tangga lazimnya mempunyai fungsi reproduksi yaitu mengalami kehamilan, melahirkan dan merawat anaknya. Dengan berkembangnya zaman wanita mempunyai peran ganda yaitu sebagai ibu rumah tangga dan bekerja di luar rumah. Keinginan kaum wanita untuk melaksanakan berbagai peran tersebut dapat mengakibatkan ketegangan dalam diri mereka. Gejala yang sering ditemukan yaitu gejala fisik dan kelelahan jiwa. Gejala fisik dapat berupa keletihan, merasa lelah, tidak fit, bahkan sakit sakitan. Kelelahan jiwa misalnya; merasa tegang, cemas, kurang tidur, dan kelelahan nafsu makan. Oleh karena itu, semua wanita memerlukan tingkat kebugaran yang cukup untuk dapat melakukan pekerjaan mereka sehari-hari tanpa menimbulkan kelelahan yang berlebihan.

Kebugaran jasmani adalah kesanggupan dan kemampuan tubuh untuk melakukan tugas pekerjaan sehari - hari dengan efisien tanpa menimbulkan kelelahan yang berarti. Seseorang yang kebugaran jasmaninya 
baik, maka akan dapat melakukan kegiatan rutin tanpa terlalu lelah, bahkan dapat bekerja lebih banyak dan masih dapat menikmati waktu senggangnya. Kebugaran dapat diperoleh dengan tiga hal yaitu: melakukan olah raga dalam jumlah yang cukup dan ter-atur, mendapatkan gizi yang memadai untuk kegiatan fisiknya, serta cukup tidur.

Menurut Moeloek (2000), kebugaran seseorang dipengaruhi antara lain oleh; olah raga, aktivitas fisik, status gizi, kadar HB, usia, kecukupan tidur. Status gizi kurang akan mencerminkan kualitas fisik yang rendah, memberi dampak menurunnya tingkat kebugaran yang akan berdampak terhadap rendahnya kemampuan kerja (Krisdinamurtirin, 1999). Seseorang yang berolah raga dapat menyediakan oksigen hampir 2 kali lipat per menit daripada tidak ber olah raga dan kurang tidur mempunyai efek yang sangat besar pada mental dan penampilan fisik seseorang (Sumosardjuno dan Wirosuhardjo, 2000).

Berdasarkan survey pendahuluan pada 10 wanita peserta Sanggar Senam Taurus menunujukan bahwa dalam menjaga penampilan fisiknya, $70 \%$ wanita tersebut dalam kondisi bugar, 55\% melakukan diet makanan tanpa diimbangi dengan melakukan olah raga secara teratur. Tujuan pene- litian ini adalah untuk mengkaji dan menganalisis Kebugaran wanita dilihat dari kecukupan gizi, status gizi, kecukupan tidur, frekuensi olah raga.

\section{METODE PENELITIAN}

Jenis penelitian ini adalah survey eksplanatory analitik dengan pendekatan cross sectional. Populasi dalam penelitian ini adalah seluruh wanita peserta senam di Sanggar Senam Taurus Surabaya sebanyak 90 orang. Besar sampel dalam penelitian ini adalah 60 orang dimana masing - masing kelompok diambil 12 orang dengan teknik proporsional simple random sampling. Variabel bebas pada penelitian ini adalah kecukupan gizi, status gizi, kebiasaan aktivitas (frekuensi olah raga, kecukupan tidur) dan sebagai variable terikatnya adalah kebugaran. Instrumen form Recall 2x24 jam digunakan untuk mengumpulkan data kecukupan gizi. Timbangan injak dan microtoise digunakan untuk mengukur berat badan/tinggi badan. Instrumen kuesioner digunakan untuk mengumpulkan data aktifitas (frekuensi olah raga, tidur). Bangku Harvard dengan tinggi $40 \mathrm{~cm}$ digunakan untuk mengetahui tingkat kebugaran responden. Analisis data dengan menggunakan uji Chi Square. 


\section{HASIL DAN PEMBAHASAN}

Tabel 1. Distribusi Frekuensi Kecukupan Gizi pada Wanita Peserta Senam di Sanggar Taurus Surabaya

\begin{tabular}{cccccc}
\hline & & \multicolumn{5}{c}{ Kecukupan Gizi } \\
\cline { 3 - 6 } No & Unsur Zat Gizi & \multicolumn{3}{c}{ Cukup } & \multicolumn{2}{c}{ Tidak Cukup } \\
\cline { 3 - 6 } & & N & $\%$ & N & $\%$ \\
\hline $\mathbf{1}$ & Kalori & 59 & 96,66 & 2 & 3,33 \\
$\mathbf{2}$ & Karbohidrat & 58 & 96,66 & 2 & 3,33 \\
$\mathbf{3}$ & Protein & 55 & 91,7 & 5 & 8,3 \\
$\mathbf{4}$ & Lemak & 55 & 91,7 & 5 & 8,3 \\
$\mathbf{5}$ & Fe & 52 & 86,7 & 8 & 13,3 \\
$\mathbf{6}$ & Vitamin B1 & 53 & 88,3 & 7 & 11,7 \\
$\mathbf{7}$ & Calsium & 36 & 60 & 24 & 40 \\
\hline Jumlah & \multicolumn{5}{c}{} \\
\hline
\end{tabular}

Tabel 2. Distribusi Frekuensi Status Gizi pada Wanita Peserta Senam di Sanggar Taurus Surabaya

\begin{tabular}{ccc}
\hline Status Gizi & Jumlah & Persentase \\
\hline Gizi baik & 54 & 90 \\
Gizi Kurang & 6 & 10 \\
\hline Jumlah & 60 & 100 \\
\hline
\end{tabular}

Tabel 3. Distribusi Frekuensi Aktivitas pada Wanita Peserta Senam di Sanggar Taurus Surabaya

\begin{tabular}{clcc}
\hline Aktivitas & Katagori & $\mathrm{N}$ & $\%$ \\
\hline \multirow{3}{*}{ Olah Raga } & Teratur & 43 & 71,7 \\
& Tidak Teratur & 17 & 28,3 \\
& Jumlah & 60 & 100 \\
\hline \multirow{3}{*}{ Tidur } & Cukup & 48 & 80 \\
& Tidak Cukup & 12 & 20 \\
& Jumlah & 60 & 100 \\
\hline \multirow{3}{*}{ Status Aktivitas } & Aktif & 43 & 71,7 \\
& Tidak aktif & 17 & 28,3 \\
& Jumlah & 60 & 100 \\
\hline
\end{tabular}

Tabel 4. Distribusi Frekuensi Kebugaran pada Wanita Peserta Senam di Sanggar Taurus Surabaya

\begin{tabular}{lcc}
\hline Kebugaran & Jumlah & Persentase \\
\hline Bugar & 42 & 70 \\
Tidak bugar & 18 & 30 \\
\hline Jumlah & 60 & 100 \\
\hline
\end{tabular}


Tabel 5. Distribusi Frekuensi Kebugaran Menurut Kecukupan Gizi pada Wanita Peserta Senam di Sanggar Taurus Surabaya

\begin{tabular}{|c|c|c|c|c|c|c|c|}
\hline \multirow{3}{*}{ Unsur Gizi } & \multirow{3}{*}{ Kecukupan } & \multicolumn{4}{|c|}{ Kebugaran } & \multirow{2}{*}{\multicolumn{2}{|c|}{ Jumlah }} \\
\hline & & \multicolumn{2}{|c|}{ Bugar } & \multicolumn{2}{|c|}{ Tidak Bugar } & & \\
\hline & & $\mathrm{N}$ & $\%$ & $\mathrm{n}$ & $\%$ & $\mathrm{~N}$ & $\%$ \\
\hline \multirow[t]{3}{*}{ Kalori } & Cukup & 41 & 68,3 & 17 & 28,3 & 58 & 96,7 \\
\hline & Tidak Cukup & 1 & 1,7 & 1 & 1,7 & 2 & 3,3 \\
\hline & Jumlah & 42 & 70 & 18 & 30 & 60 & 100 \\
\hline \multirow[t]{3}{*}{ Karbohidrat } & Cukup & 41 & 68,3 & 17 & 28,3 & 58 & 96,7 \\
\hline & Tidak cukup & 1 & 1,7 & 1 & 1,7 & 2 & 3,3 \\
\hline & Jumlah & 42 & 70 & 18 & 30 & 60 & 100 \\
\hline \multirow[t]{3}{*}{ Protein } & Cukup & 39 & 65 & 16 & 26,66 & 95 & 91,7 \\
\hline & Tidak cukup & 3 & 5 & 2 & 3,33 & 5 & 8,3 \\
\hline & Jumlah & 42 & 70 & 18 & 30 & 60 & 100 \\
\hline \multirow[t]{3}{*}{ Lemak } & Cukup & 39 & 65 & 16 & 28,3 & 56 & 91,7 \\
\hline & Tidak cukup & 3 & 5 & 2 & 1,7 & 4 & 8,3 \\
\hline & Jumlah & 42 & 70 & 18 & 30 & 60 & 100 \\
\hline \multirow[t]{3}{*}{$\mathrm{Fe}$} & Cukup & 37 & 61,7 & 15 & 25 & 52 & 86,7 \\
\hline & Tidak cukup & 5 & 8,3 & 3 & 5 & 8 & 13,3 \\
\hline & Jumlah & 42 & 70 & 18 & 30 & 60 & 100 \\
\hline \multirow[t]{3}{*}{ Vitamin B1 } & Cukup & 36 & 60 & 17 & 28,3 & 53 & 88,3 \\
\hline & Tidak cukup & 6 & 10 & 1 & 1,7 & 7 & 11,7 \\
\hline & Jumlah & 42 & 70 & 18 & 30 & 60 & 100 \\
\hline \multirow[t]{3}{*}{ Calsium } & Cukup & 30 & 50 & 6 & 10 & 36 & 60 \\
\hline & Tidak cukup & 12 & 20 & 12 & 20 & 24 & 40 \\
\hline & Jumlah & 42 & 70 & 18 & 30 & 60 & 100 \\
\hline
\end{tabular}

Tabel 6. Distribusi Frekuensi Kebugaran Menurut Satus Gizi pada Wanita Peserta Senam di Sanggar Taurus Surabaya

\begin{tabular}{lccccccc}
\hline \multirow{3}{*}{ Status Gizi } & \multicolumn{4}{c}{ Kebugaran } & \multicolumn{2}{c}{ Total } \\
\cline { 2 - 6 } & \multicolumn{3}{c}{ Bugar } & \multicolumn{2}{c}{ Tidak Bugar } & & \\
\cline { 2 - 6 } & $\mathrm{n}$ & $\%$ & $\mathrm{n}$ & $\%$ & $\mathrm{~N}$ & $\%$ \\
\hline Gizi baik & 38 & 63,33 & 16 & 26,66 & 54 & 90 \\
Gizi Kurang & 4 & 6,66 & 2 & 3,33 & 6 & 10 \\
\hline Jumlah & 42 & 70 & 18 & 30 & 60 & 100 \\
\hline
\end{tabular}

Tabel 7. Distribusi Frekuensi Status Gizi pada Wanita Peserta Senam di Sanggar Taurus Surabaya

\begin{tabular}{|c|c|c|c|c|c|c|c|}
\hline \multirow{3}{*}{ Aktivitas } & \multirow{3}{*}{ Katagori } & \multicolumn{4}{|c|}{ Kebugaran } & \multirow{2}{*}{\multicolumn{2}{|c|}{ Total }} \\
\hline & & \multicolumn{2}{|c|}{ Bugar } & \multicolumn{2}{|c|}{ Tidak Bugar } & & \\
\hline & & $\mathrm{N}$ & $\%$ & $\mathrm{~N}$ & $\%$ & $\mathrm{n}$ & $\%$ \\
\hline \multirow{3}{*}{ Olah Raga } & Teratur & 30 & 50 & 13 & 21,7 & 43 & 63,7 \\
\hline & Tidak Teratur & 12 & 20 & 5 & 8,3 & 17 & 28,3 \\
\hline & Jumlah & 42 & 70 & 18 & 30 & 60 & 100 \\
\hline \multirow{3}{*}{ Tidur } & Cukup & 33 & 55 & 15 & 25 & 48 & 80 \\
\hline & Tidak cukup & 9 & 15 & 3 & 5 & 12 & 20 \\
\hline & Jumlah & 42 & 70 & 18 & 30 & 60 & 100 \\
\hline
\end{tabular}


Tabel 8. Hasil Uji Chi Square

\begin{tabular}{lcc}
\hline \multicolumn{1}{c}{ Variabel } & df & Sig (p) \\
\hline Kecukupan kalori & 1 & 0,0031 \\
Kecukupan karbohidrat & 1 & 0,0390 \\
Kecukupan protein & 1 & 0,0052 \\
Kecukupan lemak & 1 & 0,0455 \\
Kecukupan Fe & 1 & 0,0002 \\
Kecukupan calcium & 1 & 0,0465 \\
Status Gizi & 1 & 0,0300 \\
olah raga & 1 & 0,0172 \\
Kecukupan tidur & 1 & 0,0480 \\
Kecukupan aktivitas & 1 & 0,0270 \\
\hline
\end{tabular}

Kebugaran erat hubungannya dengan input zat - zat gizi dan proses pengolahan biologis serta kemungkinan fisiologis yang ditimbulkan. Menurut Moeloek (2000), kebugaran seseorang dipengaruhi antara lain oleh; olah raga, aktivitas fisik, status gizi, kadar HB, usia, kecukupan tidur. Status gizi kurang akan mencerminkan kualitas fisik yang rendah, memberi dampak menurunnya tingkat kebugaran yang akan berdampak terhadap rendahnya kemampuan kerja.. Kenyataan memperlihatkan bahwa individu yang kurang gizi mempunyai kemampuan yang lebih rendah daripada mereka yang cukup gizi, dan kemampuan akan berkurang dengan habisnya cadangan makanan selama melangsungkan kegiatan.

Hasil penelitian pada uji statistic Chi-Square menunjukkan bahwa terdapat hubungan yang signifikan ( $p$ $<0,05$ ) antara kecukupan gizi besi, frekuensi olah raga terhadap kebugaran. Yang berarti terdapat pengaruh antara kecukupan gizi, frekuensi olahraga terhadap kebugaran. Fungsi utama besi adalah mengantarkan oksigen ke dalam jaringan tubuh dan turut mekanisme oksidasi seluler. Bila zat besi tidak cukup tersedia maka secara tidak langsung tenaga akan berkurang (Ristrini, 1999).

Hasil penelitian pengukuran konsumsi makanan menunjukkan $86,7 \%$ sampel mengkonsumsi gizi besi cukup, dengan rata-rata konsumsi 19,38 mg (77\% RDA) dan 13,3\% sampel mengkonsumsi kurang gizi besi (ratarata konsumsi $17,8 \mathrm{mg}$ atau $68,72 \%$ RDA). Pada individu dengan tingkat konsumsi gizi kurang mempunyai nilai IKB (Indek Kemampuan Badan) 1,27 kali lebih rendah disbanding jika tingkat konsumsi gizi cukup.

Anemi gizi terutama disebabkan kekurangan zat besi disebut anemi kurang besi. Menurut Ristrini (1999), mengemukakan adanya hubungan antara anemi gizi besi, defisiensi vitamin $\mathrm{B}_{12}$ dan asam folat. Penyerapan 
zat besi dari makanan oleh usus dipengaruhi oleh bentuk $z_{t}$ besi dalam makanan serta terdapatnya zat-zat yang dapat menghambat atau meningkatkan penyerapan. Zat besi "heme" yang berasal dari bahan pangan hewani lebih mudah diserap (sekitar 10-20\%). Sedangkan besi "non heme" berasal dari bahan pangan nabati sulit untuk diserap (hanya 1-5\%). Zat-zat yang dapat menghambat penyerapan besi anatra lain : asam fitat, asam oksalat, dan tannin (terdapat dalam serealia, kacang dan teh).

Dari hasil "food recall" diketahui bahwa sampel mempunyai pola makanan yang sebagian besar $(75,6 \%)$ terdiri dari menu yang kurang beraneka ragam, susunan konsumsi tergolong pada tipe makanan rendah absorbs zat besi (konsumsi protein hewani lebih rendah daripada nabati). Menurut Husaini (1999), pada keadaan anemi menunjukkan kemampuan kerja rendah; $20 \%$ lebih rendah dari keadaan tidak anemi. Hasil penelitian Karyadi dan Muhilal (1999) mengemukakan ada korelasi positif dan bermakna antara kadar zat besi dengan skor uji Naik Turun Bangku Harvard (NTB) untuk menilai tingkat kebugaran. Hal ini sesuai dengan data Nieman yang dikutip Karyadi dan Muhilal (1999) yang menyatakan skor NTB pada keadaan anemi lebih rendah dibanding keadaan tidak anemi.

Pengukuran kebugaran dengan tes naik turun bangku Harvard pada penelitian ini menunjukan bahwa sampel pada tingkat konsumsi zat besi cukup mempunyai tingkat kebugaran lebih tinggi dibandingkan jika konsumsi zat besi kurang. Penelitian imunologik Soenarko (2000) pada penderita anemi gizi besi terdapat penurunan kekebalan tubuh seperti turunnya jumlah T-lymphocyte, kekurangan grabulocyte myeloperoxidase sehingga menyebabkan daya tahan tubuh menurun dan tingkat kebugaran rendah.

Hasil penelitian Karyadi dan Muhilal (1999) mengenai efek suplementasi besi berupa $100 \mathrm{mg}$ unsur besi sehari selama 8 minggu menunjukkan kenaikan kadar haemoglobin, hematokrit, besi serum. Dengan suplementasi lebih tampak pengaruhnya terhadap kenaikan skor NTB (kebugaran) daripada pemberian Combantrin.

Menurut Wipple yang dikutip Karyadi dan Muhilal (1999), mengungkapkan bahwa konsumsi energi dan protein berkorelasi positif dengan tingkat kadar haemoglobin. Lebih lanjut dilaporkan bahwa pembentukan sel-sel darah merah dapat berlangsung dengan menggunakan protein tubuh meskipun tubuh dalam keadaan defisiensi protein. Jadi ada indikasi bahwa penambahan konsumsi pada umumnya mengakibatkan kenaikan haemoglobin. Konsumsi besi bermakna pada $\mathrm{p}<0,05$, jadi dapat diperhitungkan ratarata pekerja yang tidak anemi mengkonsumsi 1,2 gram tambahan besi sehari cukup untuk mempertahankan 
keseimbangan kadar Fe dalam serum darah.

Kebiasaan olahraga merupakan faktor yang dapat mempengaruhi tingkat kebugaran seseorang. Kebugaran tidak hanya ditentukan oleh tenaga dan perkembangan otot, tetapi terutama oleh kapasitas jantung dan paru-paru untuk melimpahkan oksigen dan darah keseluruh jaringan tubuh atau disebut juga kapasitas aerobic daya tahan ('endurance') adalah keadaan yang menekankan pada kapasitas melakukan kerja secara terus-menerus dalam suasana aerobic.

Untuk meningkatkan dan memelihara kardiorespirasi, komposisi badan dan kekuatan otot, serta "endurance" adalah dengan melakukan olahraga atau latihan-latihan secara teratur dan rutin (Gian, 1993).

Adapun prinsip-prinsip latihan atau olahraga mengikuti anjuran "FITT" (Frekuensi, Intensitas, Tipe, Time). Anjuran FITT tersebut menurut Gian, (1993) adalah sebagai berikut:

F (Frekuensi): 3-6 kali per minggu

I(Intensitas) : \pm 60-85\% dari denyut jantung maksimal. Peran denyut jantung sangat penting karena merupakan dasar untuk memperkirakan beban kerja pada tingkatan yang tepat dalam berbagai keadaan kerja.

Tipe : Suatu kombinasi dari latihan aerobic dan aktivitas kalistemik.
Time

: Waktu 15-60 menit latihan aerobic terus menerus, sebelumnya didahului 3-5 menit pemanasan dan diikuti oleh 3-5 menit pendinginan berupa latihan kalistemik.

Berdasarkan hasil penelitian terdapat sebanyak $71,7 \%$ sampel melakukan olah raga secara teratur yaitu e" 3 x per minggu. Dan sebanyak $17 \%$ sampel melakukan olahraga secara tidak teratur. Pada sampel yang melakukan olahraga secara teratur mempunyai nilai $1 \mathrm{~KB} 15 \%$ lebih tinggi dibandingkan bila sampel melakukan olahraga secara tidak teratur.

Latihan atau olahraga yang dilakukan 3 kali per minggu akan memberi efek yang lebih terhadap kebugaran, sedangkan latihan fisik atau olahraga yang dilakukan kurang dari 3 kali per minggu tidak member pengaruh yang berarti bagi peningkatan kebugaran (Sumosardjuno dan Wirosuhardjo, 2000).

Sebagian besar $(81 \%)$ sampel melakukan latihan aerobic dengan senam dan jogging. Aktivitas demikian merupakan aktivitas terpenting untuk semua orang, tidak memandang umur, sex, tingkat kesehatan, status sosial ekonomi. Dari hasil wawancara terdapat sebanyak $75 \%$ sampel melakukan latihan kalistemik dengan memutar pinggang dan sit up. Latihan- 
latihan demikian terutama bermanfaat untuk meningkatkan kekuatan otot, ketahanan otot dan kelenturan sendi dan otot. Komponen kebugaran ini bersama-sama dengan kebugaran aerobic merupakan komponen yang terpenting untuk semua orang, termasuk untuk mereka yang bergerak.

Menurut Moeloek (2000), olah raga dilakukan dengan waktu, jumlah dan frekuensi akan mempunyai dampak positif pada tubuh, antara lain:

a. Peningkatan efisiensi kerja paru Seseorang yang terlatih dapat menyediakan oksigen hamper dua kali lipat per menit daripada tidak terlatih.

b. Peningkatan efisensi kerja jantung Jantung semakin kuat dan dapat memompa lebih banyak darah, akibatnya orang terlatih akan mempunyai denyut jantung lebih lambat 20 kali per menit daripada yang tidak terlatih.

c. Peningkatan jumlah dan ukuran pembuluh darah yang menyalurkan darah keseluruh tubuh.

d. Peningkatan ketegangan otot dan pembuluh darah yang seringkali bisa menurunkan tekanan darah tinggi.

e. Peningkatan volume darah yang mengalir keseluruh tubuh. f. Mengubah tubuh yang berlemak, menjadi tubuh tegap berisi.

g. Peningkatan konsumsi oksigen maksimal.

Hasil penelitian ini menunjukkan terjadi peningkatan kondisi tubuh yang secara menyeluruh, terutama organ-organ penting seperti paru, jantung, pembuluh darah dan keseluruhan jaringan tubuh, sehingga akan memperkuat daya tahan tubuh.

\section{KESIMPULAN DAN SARAN}

\section{A. Kesimpulan}

Ada hubungan antara kecukupan gizi, status gizi, kecukupan tidur, frekuensi olahraga dan status aktivitas dengan kebugaran.

\section{B. Saran}

1. Disarankan pada wanita dan masyarakat pada umumnya untuk memperbaiki pola makanan yaitu pola makanan dengan menu beraneka ragam, mengkonsumsi protein hewani lebih banyak daripada nabati, mengkonsumsi cukup vitamin C

2. Disarankan pada wanita dan masyarakat melakukan olah raga yang teratur dan istirahat yang cukup. 


\section{DAFTAR PUSTAKA}

Gian, C.K., 1993. Ilmu Kedokteran Olah raga. Jakarta: Bimarupa Aksara.

Husaini, M. A., Suharno, D., Husaini Y. K., dan Siagion, U.L. 1999. Study Nutrition and Assesment of Information Compilition for Supporting and Formulating National Policy and Program. Jakarta : Departemen Kesehatan.

Karyadi, D dan Muhilal. 1999. Kecukupan Gizi yang Dianjurkan. Jakarta : PT. Gramedia Pustaka Utama.

Krisdinamurtirin, Y. 1999. Status Gizi dalam Hubungannya dengan Kesegaran Jasmani sebagai Penunjang Produktivitas Kerja. Bogor : Puslitbag Gizi.

Moeloek, D., 2000. Dasar Fisiologi Kesegaran Jasmani dan Latihan Fisik Kesehatan dan Olahraga. Jakarta: Balai Penerbitan Fakultas Kedokteran.

Ristrini. 1999. Anemi Akibat Kurang Zat Besi, Keadaan, Masalah, dan Program Penanggulangannya. Medika. No. 1, 17 Januari, Jakarta.

Sunarko S. 2000. Olah Raga Praktis Bagi Wanita Aktif. Surabaya : Laboratorium Ilmu Faal Fakultas Kedokteran, Universitas Airlangga.

Sumosardjuno dan Wirosuhardjo. 2000. Pendekatan Gizi dan Olahraga Dalam Peningkatan Kualitas Fisik Sumberdaya Manusia. Jakarta: Akademi Gizi. 